\title{
THE IMPACT OF RESEARCH AND DEVELEOPMENT ON REVENUE GENERATION AND INVESTMENT VALUATION OF INFO-TECH CORPORTIONS
}

DOI: 10.17261/Pressacademia.2015414536

Legima E. Doh', Damian R. Prince ${ }^{2}$

${ }^{1}$ Hampton University, USA. Email:legima.doh@my.hamptonu.edu

${ }^{2}$ New Jersey City University, USA. Email:dprince@njcu.edu

\section{Keywords}

research and development, information technology innovation, investment valuation

JEL Classification M41

\begin{abstract}
In today's rapidly changing business world, it has become imperative for companies to be innovative, in order to stay in business. At the heart of this approach is research and development (R\&D). While, R\&D practices differ across industries and companies, we recognize that the practice is prevalent in the pharmaceutical and the information technology (IT/ infotech) industries. Despite the fact, that much research has been done on $R \& D$ in the pharmaceutical industry, there is limited literature and research on the subject in the information technology industry. Consequently, this study is our effort to assess the impact of R\&D on revenue generation and investment valuation of IT corporations. In this study, we investigate the impact of R\&D on revenue generation and investment valuation of 40 United States (U.S.) based information technology corporations. We find that info-tech companies that invest more on R\&D generate more revenue. We also find that investors place higher value on corporations that invest larger parts of their revenues on $R \& D$. This suggests that investors expect higher earnings growth in the future of companies that invest greater parts of their revenues on R\&D.
\end{abstract}

\section{INTRODUCTION}

For companies to survive in today's competitive domestic and global business environments, they must engage in practices that enable them to keep producing high quality products that can satisfy the complex and constantly changing needs of customers. Consequently, each year, many businesses in the commercial world spend vast amounts of money, on the research and development (R\&D) of products and services. By developing products and services that satisfy and meet the needs of customers, businesses hope to enhance their profits (ACCA, 2007). 
The importance of research and development is so great that countries are divided into developed and undeveloped countries, based on the funds devoted to R\&D (ACCA, 2007). Accountants and various researchers have used different methods of research in their attempt to assess the contribution of research and development expenditures (cost) on economic growth: historical case studies and econometric estimates of production functions containing R\&D variables (Griliches, 1979).

In addition, to enhancing a firm's profit, investing in research and development can also stimulate economic growth and social development (Abdi, 2007). Furthermore, R\&D is one of the few variables, which public policy can affect in the future and has affected in the past (Griliches, 1979). As a result, the amount of money a business devotes to R\&D can be influenced by public policy.

At the moment, $78 \%$ of global research and development occurs in five countries; the United States of America (USA), Japan, Germany, France and the United Kingdom (UK) (The R\&D Scoreboard, 2010). Globally, five sectors continue to dominate spending on R\&D. Three of the sectors are also among the five largest-spending sectors in both the USA and the UK: pharmaceuticals and biotechnology, software and computer services and automobiles and parts. Technology hardware and equipment, and electronic and electrical equipment complete the global top five R\&D sectors (R\&D scoreboard).

Despite the fact, that much research has been done on R\&D in the pharmaceutical industry, there is limited literature and research on the subject in the information technology industry. This is a rather curious situation, considering that we live in the information age, in which technology permeates every aspect of business. For example, there are significant relationships among technology use, social networks, completed projects and revenues for projects-based information workers (Aral et al., 2007). In fact, since the 1990s, one of the main tools that have been transforming businesses, the way Taylorism (production efficiency methodology) once did, is information technology, the capabilities offered by computers, software applications and telecommunications (Davenport \& Short, 1990).

As Luftman, Lewis and Oldbach (2010) stated, "the strategic use of information technology is now and has been a fundamental issue for every business". Hence, it is of considerable importance that we increase our knowledge on this important subject, by studying how it affects the information technology industry. In this paper, we study the efficacy of research and development costs on revenue generation and on investment valuation of 40 U.S. based information technology corporations. To begin, we provide definitions of key words; and then present the theoretical principles and empirical literature on the relationship between $R \& D$ spending and the financial performance of business entities.

We also point out in this paper what certain research approaches on the effects of R\&D spending can and cannot accomplish. For example, given good data, the production approach can tell us about the average returns on R\&D investments in the past and whether they appear to be changing over time. The production approach may be able to indicate the industries where returns have been especially high or low, but it will not be able to indicate whether a particular R\&D proposal is a good bet or not (Griliches, 1979). 
To the extent that the output of invention-using industries is well measured, the returns to research and development can be found in the aggregate data (Griliches, 1979). However, in many important invention-using industries, such as health, education and government, where output is difficult to measure, the contribution of R\&D may be hard to determine. Since, the information technology industry does not fall within this category; we do not face the aforementioned challenge in this study.

The U.S Office of Management and Budget (OMB, 2015) defines research and development as creative work that is undertaken on a systematic basis in order to increase the stock of knowledge, including knowledge of man, culture and society, and the use of this stock of knowledge to devise new applications. Research and development costs include all the resources spent for the activities that are particularly suitable for the production of the planned products and services. These activities can either be outsourced by a single organization or performed by an independent unit within the organization (Britt, 2007).

According to the United States Federal Accounting Standards Advisory Board (FASAB, 2015), "Investment in research and development" refers to those expenses incurred to support the search for new or refined knowledge and ideas and for the application or use of such knowledge and ideas for the development of new or improved products and processes with the expectation of maintaining or increasing national economic productive capacity or yielding other future benefits. Research and development is composed of:

- Basic research: systematic study to gain knowledge or understanding of the fundamental aspects of phenomena of observable facts without specific applications toward processes or products in mind.

- Applied research: systematic study to gain knowledge or understanding necessary for determining the means by which a recognized and specific need may be met; and

- Development: systematic use of knowledge and understanding gained from research for the production of useful materials, devices, systems, or methods, including the design and development of prototypes and processes. Statement of Federal Financial Accounting Standards No. 8: Supplementary Stewardship Reporting, chapter 7, paragraph 96, is devoted to research and development.

Innovation is the translating of ideas into products and services that create worth for which customers are willing to pay (Business dictionary, 2015). Incremental innovations occur in the form of product and service enhancements and radical innovations result in the creation of new products and services (Laura, 2000).

Investment valuation is the process of determining the current worth of an asset or a company (investopedia, 2015). The most well known investment valuation method is the use of the price-to-earnings ( $\mathrm{P} / \mathrm{E}$ ) ratio, which compares the current price of a company's shares to the amount of earnings it generates. The purpose of this ratio is to give users an idea of how much they are paying for each dollar of earnings. 
Thong and Yap (1995) defined information technology as "computer hardware and software that provide support for operations, management and strategists in organizations." Two years later, Boar (1997) defined it as "those technologies engaged in the operation, collection, transport, retrieving, storage, access, presentation, and transformation of information in all its forms." Hollander et al. (1999) posited that information technology can be regarded as technological aspects of information as it is reported. All these definitions broadly capture what information technology encompasses. Sarasoza and Zowghi (2003) added to the definition by asserting that "information technology is aimed for the creation of computer-based systems of information by using computer systems." Recently, Tan et al. (2009) defined it as "the application of information and communication technology tools including computer network, software and hardware required for internet connection." The idea of creating brings research and development at the core of information technology. Info-tech corporations, therefore place significant importance on R\&D which leads to innovation. The term information technology also includes any computer application and required packages of hardware, computer-aided manufacturing, computer-aided design, electronic data interchange, enterprise resource planning that positively affect the productivity of an organization (Oon \& Sorooshian, 2013).

\section{LITERATURE REVIEW}

Perry and Grinaker (1994) studied profitability expectations, discretionary research and development costs in the United States of America. In their study, they investigated the ratio between R\&D and profitability of 90 major USA companies. Their results showed that the profitability of research and development is effective. This effect was more than a quarter of the total impact on profitability. Also, research and development has been associated with an increase in prosperity, but in times of recessions, it has been reduced. Franzan and Radhakrishnan (2009) evaluated the relationship between R\&D costs and profitability or loss. They applied the residual earnings model to illustrate that the multiplier for R\&D costs would probably be negative (positive) for profit (loss) generating firms. This is due to the fact that the dynamics of linear information in the residual earnings model is mostly appropriate for profit generating firms rather than for loss generating ones. Also, the income statement for income generating firms includes information on future benefits of R\&D; while no such information is presented in the income statement of loss generating firms. Empirical evidence approves predictions made by researchers for loss generating firms. Rockoff (2009) believes that the high value of a product is not necessarily due to the traditional strategies of high risk R\&D activities, however he asserted that, concentration on activities with economic merits and the control of the cost of production and assets would not be possible without the application of R\&D strategies. Asthana and Yinqi (2006) applied the Olson evaluation model to examine the relationship between R\&D costs and the persistence of abnormal earnings. According to their research which was carried out from 1982 to 2001, contrary to previous studies which considered the industry as an R\&D index, R\&D costs were divided into two categories. The first category included average industry R\&D costs (industry influenced) 
and the second involved companies focused on R\&D costs (company influenced). Ultimately, the effects of both categories on the persistence of abnormal earnings were studied. They found that both categories have a positive relationship with abnormal earnings. Moreover, the positive effect of the efficiency of R\&D costs on earnings persistence and the creation of a competitive merit are quite more significant than the negative effects of $R \& D$ project risks. Also it is not only the industry which plays a role in predicting earnings persistence, but rather it is the investment of the owners in R\&D costs that is indicative of the firm's efforts in producing diverse and different products and the measurement of earnings persistence.

Nvark (2001) investigated the relationship between growth, profitability and costs of research and development using simultaneous equations model. In his study, the relationship between firm size and $R \& D$, and other factors affecting research and development in its various forms were investigated. The results of his study show a significant and positive effect of firm size on research and development, and mutual profitability and growth in profitability. Jones (2000) looked at the effect of profit and other information in assessing the companies that have research and development costs. His sample included 144 companies in four industries in 1977: market value by the variable operating profit, operating assets, book value, profit sharing and other data were considered. The results showed that operating profit and the persistence of abnormal profit of firms with research and development expenses are higher than for those that lack such expenses.

Laura (2000) showed that more innovations occur in the form of enhancements and radical innovations in the form of new products for companies that spend more on R\&D. The results of her study also show that input, behavior, and output controls enhance radical innovation, and input and output controls enhance incremental innovation. Due to the importance of R\&D, over time, it has reached and held a central place in the discourses and policies on science, technology and innovation (Godin \& Lane, 2012)

\section{DATA AND METHODOLOGY}

In this study, we use data compiled by Business Week for the top 100 information technology companies in the world. Business Week's financial data comes from Standard \& Poor's (S\&P), a division of the McGraw-Hill Companies that has computerized information on 10,000 publicly traded corporations. To qualify for our sample, companies had to have revenues of at least $\$ 300$ million. For our sample, we selected all the U.S. based corporations that made the 2014 Business Week's list of top 100 global information technology companies. After selecting all the U.S. based corporations, we eliminated those that did not have publicly published financial statements. We also eliminated companies that did not report information on R\&D. All the companies in our sample stated in their annual reports that they strongly depend on R\&D to keep producing innovative products. Finally, we arrived at 40 U.S. based companies, all of which have publicly published financial records available on www.sec.gov and www.last10k.com. Using these two websites, for each company, we compiled data on 2010 R\&D spending, 
2010 Revenue, 2010 R\&D intensity (calculated by dividing 2010 R\&D spending by 2010 Revenue), 2014 R\&D spending, 2014 Revenue and 2014 R\&D intensity (R\&D intensity is denoted as $\mathrm{R} \& \mathrm{Di}$ ). We obtained price-to-earnings (P/E) ratios of the companies in our sample from S\&P 500, and www.yahoofinance.com. After obtaining the data, we entered it into an Excel spreadsheet. Please see Appendix 1. We used 2014 revenue to test for the effect of 2010 R\&D spending because R\&D matures in four years i.e. its effect is expected to manifest four years after incurring the cost (Hajiheydari et. al, 2011). We ranked the companies into four categories, i.e. high R\&D and low R\&D, high R\&D intensity and low R\&D intensity (Appendix 2). The first two categories were used to investigate whether companies that spend more on R\&D (dollar value) generate more revenue than those that spend less. The last two categories were used to test for whether investors place more value on companies that spend greater parts of their revenues on R\&D than those that spend smaller parts of their revenues on R\&D. We used each company's 2015 P/E ratio for this test. This enabled us to assess how investors valued R\&D when making investment decisions in 2015.

To rank the companies into high and low R\&D categories, we sorted the companies in descending order in the Excel spreadsheet based on 2010 R\&D spending. The first twenty companies formed the high R\&D category, while the remaining twenty companies made up the low R\&D category. We used these rankings to test for difference in the means of the 2014 revenues generated by the high and the low R\&D companies. To rank the companies into high and low R\&D intensity categories, we sorted the companies in descending order based on 2014 R\&D intensity. The first twenty companies formed the high R\&D intensity category, while the remaining twenty companies made up the low R\&D intensity category. We used these two rankings to test for differences in investment valuations of the high versus the low R\&D intensity companies. This was done by testing for the difference of means of 2015 P/E ratios of the high and low R\&D intensity companies. Appendix 2 displays the categorization of the companies as previously described.

We define our hypotheses as below:

The null hypothesis $\mathrm{H}_{\mathrm{o}}$ states that there is no relationship between R\&D spending (dollar value) and revenue generation four years after incurring the cost.

The alternate hypothesis $H_{1}$ states that there is a relationship between R\&D spending (dollar value) and revenue generation four years after incurring the cost. We define further hypotheses to test for the study as below:

$\mathrm{H}_{2}$ states that companies that spend more on R\&D (dollar amount) generate more revenue than those that spend less on R\&D.

$\mathrm{H}_{3}$ states that companies that have high R\&D intensity values are valued higher by investors than those that have low R\&D intensity values. In other words, companies that spend larger parts of their revenues on R\&D are valued higher by investors compared to those that spend smaller parts of their revenues on R\&D. 
To test for $\mathrm{H}_{1}$, we used a two-variable regression test. To test for $\mathrm{H}_{2}$ and $\mathrm{H}_{3}$, we used a two sample T-test. For these statistical tests, we set our confidence level at $95 \%$ and alpha equals 5\%. We used Microsoft Excel to run our statistical tests.

\section{RESULTS}

From Table 1 below, $Y=8837+10.4 X$, where $Y$ is the dependent variable, i.e. revenue four years after R\&D spending, and $X$ is $R \& D$ spending. From this result, $R \& D$ is shown to have a positive relationship with revenue generation four years after incurring the cost. Therefore, we reject $H_{0}$, the null hypothesis and fail to reject $H_{1}$, the alternate hypothesis. Table 2 shows the outcome of the difference of means of the revenues of the high R\&D spending companies versus the low R\&D spending companies. If $t$ Stat < - $t$ Critical two-tail or t Stat $>\mathrm{t}$ Critical two-tail, then the difference between the two means is statistically significant.

Table 1: Regression Test for the Relationship between R\&D Spending and Revenue Generation

\section{SUMMARY OUTPUT}

\begin{tabular}{ll}
\hline \multicolumn{2}{l}{ Regression Statistics } \\
\hline Multiple R & 0.544023324 \\
R Square & 0.295961377 \\
Adjusted R Square & 0.277434045 \\
& \\
& \\
Standard Error & 30126.39208 \\
Observations & 40 \\
\hline
\end{tabular}

ANOVA

\begin{tabular}{|c|c|c|c|c|}
\hline & $d f$ & SS & $M S$ & $\boldsymbol{F}$ \\
\hline Regression & 1 & 14498277223 & 14498277223 & 15.974312 \\
\hline Residual & 38 & 34488780985 & 907599499.6 & \\
\hline \multirow[t]{2}{*}{ Total } & 39 & 48987058207 & & \\
\hline & Coefficients & Standard Error & t Stat & P-value \\
\hline Intercept & 8836.72983 & 6066.04793 & 1.456752392 & 0.1533989 \\
\hline X Variable 1 & 10.40146108 & 2.602455263 & 3.996787661 & 0.0002851 \\
\hline
\end{tabular}


From Table 2 below, t Stat $=2.965$, which is greater than $t$ Critical two tail $=2.079$. This indicates that the difference between the means of the revenues generated by the high $R \& D$ spending and the low R\&D spending companies is statistically significant. This implies, companies that spend more on $R \& D$ generate more revenue than those that spend less on R\&D. Therefore, we fail to reject $\mathrm{H}_{2}$.

Table 2: T-Test: Two-Sample Assuming Unequal Variances

\begin{tabular}{lll}
\hline & Variable 1 & Variable 2 \\
\hline Mean & 39018.605 & 8678.1 \\
Variance & 1995078304 & 98689894.95 \\
Observations & 20 & 20 \\
Hypothesized Mean & & \\
Difference & 0 & \\
Df & 21 & \\
t Stat & 2.965333223 & \\
$\mathrm{P}(\mathrm{T}<=t)$ one-tail & 0.003691698 & \\
t Critical one-tail & 1.720742871 & \\
$\mathrm{P}(\mathrm{T}<=\mathrm{t})$ two-tail & 0.007383396 & \\
$\mathrm{t}$ Critical two-tail & 2.079613837 & \\
\hline
\end{tabular}

Table 3 below denotes the outcome of the difference of means of the P/E ratios for high versus low $R \& D$ intensity companies. If $t$ Stat $<-t$ Critical two-tail or $t$ Stat $>t$ Critical twotail, then the difference is statistically significant. From Table $3, \mathrm{t}$ Stat $=2.424$, which is greater than $t$ Critical $=2.086$. This indicates that the difference between means of the $P / E$ ratios of high R\&D intensity companies and low R\&D intensity companies is statistically significant. From this, we find that the mean of the $P / E$ ratios of the high R\&D intensity companies is statistically and significantly higher than the mean of the P/E ratios of the low R\&D intensity companies. This implies that investors place higher value on companies that invest more of their revenues on R\&D than those that do not. Therefore, we fail to reject $\mathrm{H}_{3}$. 
Table 3: T-Test: Two-Sample Assuming Unequal Variances

\begin{tabular}{lll} 
& Variable 1 & Variable 2 \\
\hline Mean & 41.022 & 17.7225 \\
Variance & 1801.336 & 45.76507237 \\
Observations & 20 & 20 \\
Hypothesized Mean & & \\
Difference & 0 & \\
Df & 20 & \\
t Stat & 2.424467 & \\
$\mathrm{P}(\mathrm{T}<=\mathrm{t})$ one-tail & 0.012464 & \\
$\mathrm{t}$ Critical one-tail & 1.724718 & \\
$\mathrm{P}(\mathrm{T}<=\mathrm{t})$ two-tail & 0.024929 & \\
$\mathrm{t}$ Critical two-tail & 2.085963 & \\
\hline
\end{tabular}

\section{CONCLUSION}

From the results of our study, we find that when R\&D costs mature, companies that spent more on R\&D generate more revenues than those that spent less. In addition, we find that investors value companies differently based on R\&D intensity. Compared to companies that invest less of their revenues on R\&D (low R\&D intensity companies), investors' place more value, on those companies that invest more of their revenues on R\&D (high R\&D intensity companies). Therefore, when making investment decisions, investors are willing to pay more for high R\&D intensity companies. This implies that by paying more for these companies i.e. those that have high R\&D intensity indices, investors are actually investing in R\&D. The reason for this is because investors expect higher growth in the future earnings of companies that spend larger parts of their revenues on R\&D. In other words, investors invest in the future expected benefits of R\&D when making investment decisions. The results of our findings are in-line with prior studies that document increases in revenue generation and profitability due to R\&D (Grobowskey and Muller 1978; Franzan and Radhakrishnan 2009; Asthana and Yinqi 2006; Laura 2000; Nvark 2001; Jones 2000; Hajiheydari et. al 2011). One of the reasons that R\&D leads to the generation of more revenues is that it leads to the creation of innovative and new products that in turn, contribute to greater sales revenue. It is important to note that all the companies in this study affirm to the benefits of R\&D in their annual reports. For example, Applied Materials executives in the corporation's 2015 Analysts' meeting that was held on July 15, 2015 in San Francisco, showed how increasing R\&D investments over the past several 
years are resulting in innovative new products that are enabling the key technology inflections in the semiconductor and display equipment industries (Applied Materials Inc., 2015). Our study adds to the existence body of knowledge on R\&D, by showing that IT companies also greatly benefit from investing in R\&D. It also adds to the body of knowledge by showing that IT companies that spend more of their revenues on R\&D are valued higher by investors than those that spend less. In effect, we have demonstrated that R\&D increases company valuation. From this study, we have demonstrated that information technology companies can benefit from both R\&D spending (dollar amount) and $R \& D$ intensity.

\section{LIMITATIONS OF OUR STUDY}

The results of our study apply to information technology corporations that generated revenue of at least $\$ 300$ million and may not be applicable to corporations that generate less revenue, without adjustments. Our findings are also limited to the information technology companies in the United States. If replicated, findings of the same study may be different in other parts of the world and in different industries. For further studies, we recommend replicating the same study for information technology companies the world over. Future studies can also be done on how R\&D affects different industries. Studies can also be done comparing and contrasting R\&D practices among different industries, for example the pharmaceutical industry versus the information technology industry. Lastly, we recommend studying the trends of financial performance based on R\&D investments over time.

\section{REFERENCES}

Aral, S., Brynjolfsson, E., and M, Van Alstyne, 2007, "Information, technology and worker productivity: Task level evidence".

Asthana, S., and Z. Yinqi, 2006, "Effects of R\&D investments on persistence of abnormal earnings," Review of Accounting and Finance, Vol. 5, pp. 124-139.

Bixia, Xu, 2005, "R\&D strategy and stock price volatility in the biotechnology industry," Review of Accounting and Finance, Vol. 5, pp. 59-71.

Boar, B. H, 1997, "Strategic thinking for information technology: How to build the IT organization for the information age," John Wiley \& Sons, Inc. New York, NY, USA.

Davenport, T. H. and J. E. Short, 1990, "The new industrial engineering: Information technology and business redesign," Sloan Management Review, pp. 11-27.

Franzen- Laurel Radhakrishna-Suresh, 2009, "The value of relevance of R\&D across profit and loss firms," Journal of accounting, Vol. 28, 16-32. 
Godin, B., and J. P. Lane, 2012, "A Century of talks on research, what happened to development and production? International Journal of Transitions and Innovations, Vol. 2, No. 1, 5-13.

Griliches, Zvi. (1979), "Issues in Assessing the Contribution of Research and Development to Productivity Growth," The Bell Journal of Economics, Vol. 10, No. 1, pp. 92-116.

Grobowskey, H. G., and D. C. Miller, 1978, "Industrial Research and Development, Intangible Capital Stock, and Firm Profit Rates," Bell Journal of Economics, 328-343.

Hajiheydari, A., Dastgir, M., and A. Soltani, 2011, "The effects of Research and Development Costs on the Profitability of Pharmaceutical Companies," Interdisciplinary Journal of Contemporary Research in Business, Vol. 3, No. 8.

Hollander, A. and E. Denna, 1999, "Accounting, information technology, and business solutions," McGraw-Hill Higher Education

http://www.accaglobal.com/content/dam/acca/global/PDF-

students/2012/sa_sep07_retallack.pdf

http://www.appliedmaterials.com/company/news/press-releases/2015/07/applied-materialsdemonstrates-success-with-fast-ramping-

products-for-semiconductor-and-display-industries

http://www.fasab.gov/pdffiles/sffas-8.pdf

http://www.investopedia.com/terms/v/valuations.asp

http://www.whitehouse.gov/omb/circulars/a11/current year/s84.pdf

Jones, D., 2000, "The relative importance of earnings and other information in the valuation of R\&D intensive firms- Doctoral Dissertation," the University of Chicago.

Hoon, K. Y., 2008, "Risk management framework for pharmaceutical research and development projects," International Journal of Managing Projects in Business, Vol. 11, 552565.

Laura, B. C., 2000, "Technological Innovation in the Pharmaceutical Industry: The Use of Organizational Control in Managing Research and Development," Organization Science, Vol. 12, Issue 1.

Lev, B. \& T. Sougiannis, 1996, "The Capitalization, Amortization and Value-Relevance of R\&D," Journal of Accounting and Economics, Vol. 21, 107-138 
Luftman, J. N., Lewis, P. R., and S. H. Oldbach, 1993, "Transforming the enterprise: The alignment of business and information technology strategies," IBM systems journal, 32(1), 198221.

Lewis, D. J., and P. Bohumir, 1993, "Firm value and investment in R\&D. Managerial and Decision Economics," Vol. 14, 15-24.

Mansfield, E., 1968, "Industrial Research and Technological Innovation," W.W. Norton, New York.

Newark, L., 2001, "Further Evidence of the Determinants of Industrial Research and Development using Single and Simultaneous Equation Models," 203-213.

Oon, C. W., and S. Sorooshian, 2013, "Mini Literature Analysis on Information Technology Definition," Information and knowledge management, ISSN 2224-5758 (Paper) ISSN 2224896X, Vol. 2, No. 2.

Perry, S., and R. Grinaker, 1994, "Earnings Expectations and Discretionary Research and Development Spending," Vol. 8, No. 4, 43-51.

Research and development relevant to CAT Paper 6 and ACCA Qualification Papers F3, F7, and P2, September, 2007.

Rockoff, J., 2009, "Drug Firm Leaves R\&D to Others Valeant Pharmaceuticals Prefers to Forgo the Risk, Grow through Acquisitions," Wall Street Journal, B. 6.

Sarasoza, S. and D. Zowghi, 2003, "Strategy for adopting information technology for SMEs: Experience in adopting email within an Indonesian furniture company," Electronic Journal of Information Systems Evaluation 6(2): 165-176.

Tan, K. S., and S. C. Chong, 2009, "Internet-based ICT adoption: Evidence from Malaysian SMEs," Industrial Management and Data Systems 109(2): 224-244.

The R\&D Scoreboard, Department of Business, Innovation and Skills, UK, 2010, "The top 1000 UK and 1000 global companies by R\&D Investment, Commentary and Analysis,"

Thong, J. Y. L., and C. S. Yap, 1995, "CEO characteristics, organizational characteristics and information technology adoption in small businesses." Omega 23(4): 429-442. 
Appendix 1: Study Sample Data

\begin{tabular}{|c|c|c|c|c|c|c|c|c|}
\hline & CORPORATIONS & $\begin{array}{l}\text { R\&D SPENDING } \\
2010 \text { (\$̦millions) }\end{array}$ & $\begin{array}{c}\text { Revenue } \\
\text { 2010(\$̦millions) }\end{array}$ & $\begin{array}{c}\text { R\&Di } \\
\text { (R\&D/Rev 2010) }\end{array}$ & $\begin{array}{l}\text { R\&D SPENDING } \\
2014 \text { (Șmillions) }\end{array}$ & $\begin{array}{l}\text { Revenue } 2014 \\
\text { (\$\$millions) }\end{array}$ & $\begin{array}{c}\text { R\&Di } \quad \text { (R\&D/Rev } \\
\text { 2014) }\end{array}$ & $P / E(2015)$ \\
\hline 1 & Autodesk Inc & 457 & 1713.7 & 0.266674447 & 725 & 2273.9 & 0.318835481 & 167.74 \\
\hline 2 & Marvel Technology & 828.2 & 3611.9 & 0.229298 & 1164 & 3707 & 0.31400054 & 15.56 \\
\hline 3 & Broadcom & 1762 & 6818.3 & 0.258422187 & 2373 & 8428 & 0.281561462 & 45.36 \\
\hline 4 & Yahoo & 1082 & 6324.7 & 0.171075308 & 1207 & 4618.1 & 0.261362898 & 5.36 \\
\hline 5 & Electronic Arts Inc & 1153 & 3589 & 0.321259404 & 1094 & 4515 & 0.242303433 & 27.11 \\
\hline 6 & Amgen & 2894 & 15053 & 0.192254036 & 4297 & 20063 & 0.214175348 & 22.27 \\
\hline 7 & Facebook & 144 & 1974 & 0.072948328 & 2666 & 12466 & 0.213861704 & 93.94 \\
\hline 8 & Qualcomm & 2450 & 10982 & 0.223092333 & 5477 & 26487 & 0.206780685 & 15.19 \\
\hline 9 & Intel & 6576 & 43623 & 0.150746166 & 11537 & 55870 & 0.206497226 & 12.12 \\
\hline 10 & Vmware & 653 & & 0.228561 & 1239 & 6035 & 0.205302403 & 38.44 \\
\hline 11 & Adobe Systems Inc & 680.3 & 3800 & 0.179026316 & 844.4 & 4147.1 & 0.203612163 & 112.13 \\
\hline 12 & Analog Devices & 492 & 2761.5 & 0.178164041 & 560 & 2864.8 & 0.195476124 & 27.68 \\
\hline 13 & Intuit & 573 & 3091 & 0.185376901 & 714 & 4506 & 0.158455393 & 95.63 \\
\hline 14 & Symantec & 857 & 5985 & 0.143191312 & 1039 & 6676 & 0.155632115 & 18.22 \\
\hline 15 & Google & 3762 & 29321 & 0.128303946 & 9832 & 66001 & 0.14896744 & 29.96 \\
\hline 16 & LAM Research & 373.3 & 3237.7 & 0.115298 & 716 & 5259.3 & 0.13613979 & 19.43 \\
\hline 17 & Oracle & 3254 & 26820 & 0.121327368 & 5151 & 38275 & 0.134578707 & 17.84 \\
\hline 18 & Ebay & 908 & 9156.3 & 0.099166694 & 2000 & 15198 & 0.131596263 & 14.71 \\
\hline 19 & Microsoft & 8714 & 62484 & 0.139459702 & 11381 & 86833 & 0.131067682 & 18.9 \\
\hline 20 & Activision & 642 & 4447 & 0.144367 & 571 & 4408 & 0.129537205 & 22.85 \\
\hline 21 & SanDisk & 422.6 & 3566.8 & 0.118481552 & 852 & 6627.7 & 0.128551383 & 16.4 \\
\hline 22 & CA technology & 476 & 4195 & 0.113468415 & 574 & 4515 & 0.127131783 & 15.85 \\
\hline 23 & EMC & 1888 & 17015 & 0.110960917 & 2991 & 24440 & 0.122381342 & 20.16 \\
\hline 24 & Western Digital & 611 & 9850 & 0.062030457 & 1661 & 15130 & 0.10978189 & 12.02 \\
\hline 25 & Seagate Technology & 875 & 10971 & 0.079756 & 1428 & 13739 & 0.103937696 & 9.36 \\
\hline 26 & \begin{tabular}{c|} 
Lexmark \\
International \\
\end{tabular} & 369 & 4199.7 & 0.087863419 & 355 & 3710.5 & 0.095674437 & 32.69 \\
\hline 27 & Micron technology & 624. & 8482 & 0.073567555 & 1371 & 16358 & 0.083812202 & 5.99 \\
\hline 28 & Teradata & 147 & 1936 & 0.07593 & 206 & 2732 & 0.075402635 & 15.08 \\
\hline 29 & Verisign & 53.7 & 681 & 0.078855 & 68 & 1010 & 0.067326733 & 27.16 \\
\hline 30 & Xerox & 821 & 19650 & 0.04178117 & 1231 & 19540 & 0.062998976 & 13.96 \\
\hline 31 & $\begin{array}{l}\text { Automatic Data } \\
\text { Processing Inc }\end{array}$ & 137.7 & 9879.5 & 0.013937952 & 595.4 & 12206 & 0.048779289 & 27.83 \\
\hline 32 & Cisco Systems & 5273 & 40040 & 0.131693307 & 1593 & 47142 & 0.033791523 & 16 \\
\hline 33 & Apple & 1782 & 65225 & 0.027320813 & 6041 & 182795 & 0.03304795 & 15.56 \\
\hline 34 & Commscope & 120 & 3189 & 0.037629 & 125 & 3829.6 & 0.032640485 & 27.69 \\
\hline 35 & Hewlett-Packard & 2959 & 126033 & 0.023477978 & 3447 & 111454 & 0.030927558 & 12.27 \\
\hline 36 & Applied Materials & 1144 & 9549 & 0.119803 & 338 & 13739 & 0.024601499 & 14.82 \\
\hline 37 & Lockhead Martin & 638 & 45671 & 0.013969 & 751 & 45600 & 0.016469298 & 18.31 \\
\hline 38 & General Dynamics & 1056 & 31964 & 0.033037 & 358 & 30852 & 0.011603786 & 16.46 \\
\hline 39 & Jabil Circuit & 28.1 & 12607.8 & 0.002228779 & 29 & 15762.1 & 0.001839856 & 22.53 \\
\hline 40 & SAIC & 49 & 4893 & 0.010014 & 4 & 4121 & 0.000970638 & 14.31 \\
\hline
\end{tabular}




\section{Appendix 2: Categorization of Companies for Statistical Testing}

\begin{tabular}{|c|c|c|c|}
\hline $\begin{array}{c}20 \text { High R\&D } \\
\text { (\$ amount) } \\
2010\end{array}$ & $\begin{array}{c}20 \text { Low R\&D } \\
\text { (\$ amount) } \\
2010\end{array}$ & $\begin{array}{l}20 \text { High } \\
\text { R\&D Intensity } \\
2014\end{array}$ & $\begin{array}{c}20 \text { Low } \\
\text { R\&D Intensity } \\
2014\end{array}$ \\
\hline Microsoft & Adobe Systems & Autodesk Inc. & San Disk \\
\hline Intel & VMware & Marvel Technology & CA Technology \\
\hline Cisco Systems & Activision & Broadcom & EMC \\
\hline Google & Lockheed Martin & Yahoo & Western Digital \\
\hline Oracle & Micron Technology & Electronic Arts Inc. & Seagate \\
\hline Hewlett Packard & Western Digital & Amgen & Lexmark International \\
\hline Amgen & Intuit & Facebook & Micron Technology \\
\hline Qualcomm & Analog Devices & Qualcomm & Teradata \\
\hline EMC & CA Technology & Intel & VeriSign \\
\hline Apple & Autodesk Inc & VMware & Xerox \\
\hline Broadcom & SanDisk & Adobe Systems & Automatic Data Processing Inc. \\
\hline Electronic Arts Inc & LAM Research & Analog Devices & Cisco Systems \\
\hline Applied Materials & Lexmark International & Intuit & Apple \\
\hline Yahoo & Teradata & Symantec & Commscope \\
\hline General Dynamics & Facebook & Google & Hewlett-Packard \\
\hline EBay & Automatic Data Processing Inc. & LAM Research & Applied Materials \\
\hline Seagate Technology & Commscope & Oracle & Lockheed Martin \\
\hline Symantec & VeriSign & EBay & General Dynamics \\
\hline Marvel Technology & SAIC & Microsoft & Jabil Circuit \\
\hline Xerox & Jabil Circuit & Activision & SAIC \\
\hline
\end{tabular}

